\title{
A BOTANICAL EXPEDITION TO NICARAGUA
}

\author{
Frank C. Seymour
}

That Nicaragua is the least explored botanically of all the Central American Republics was a challenge to a party of six men who in December 1968 and January 1969 made a botanical expedition to that alluring an fascinating country.

What made Nicaragua such an alluring country? Not only was it the least explored but none of our party had ever seen the tropics before. With a very few exceptions, every plant we saw was new and strange. Our avowed purpose was to do what we could in merely seven weeks toward a collection as representative as possible of the flora of Nicaragua. As Cyrus Guernsey Pringle was our illustrious predecessor in botanical exploration in tropical America, and four of us belonged to the University of Vermont whose herbarium is called by his name, we chose to call ourselves The Pringle Expedition of 1968.

Of the six men from Vermont, R. Bruce Hamblett and A. David Moore were undergraduates majoring in botany. John T. Atwood was a graduate student, also majoring in botany. The leader of the expedition, Frank C. Seymour, was associate curator of the Pringle Herbarium. The two other Vermonters were Charles E. Nichols, a dairy farmer, and David A. Dudey, a chemist. Here were assembled a wide variety of talents all united by an interest in plants and a love of adventure.

On November 14, our first detachment started from home base, Charles Nichols and David Dudey leaving Burlington, Vermont, for the long drive to Nicaragua in a Volkswagen camper, in order that our party might have transportation there by automobile. The four others from Vermont, coming by plane, met those two in Managua, the capital of the country, sometime between November 30 and December 12 . In Managua, we were joined by two students in the Escuela Nacional de Agricultura y Ganaderia (the National School of Agriculture and Animal Husbandry), Eduardo Narvaez S. and Harvey Zelaya M. Then every one was present and operations were in full swing.

We take great pleasure in acknowledging the great courtesy of Dr. Gustavo Jarquin B., Director of the just named Escuela and his staff, affording us the use of the professor's suite in the dormitory and in putting at our disposal their herbarium and botanical laboratory for pressing and drying our collections. In appreciation, we left a set of our collections for the herbarium of the School. 
Having an automobile at our disposal enabled us to reach many parts of the country which we should otherwise have missed. Many localities in western Nicaragua are connected by a system of fine hard-topped roads. Moreover, to transport thus eight men costs no more than to transport one. Economy was important to us. Each of the me $n$ who made the trip from Vermont did so at his own expense.

Fortunately, the holiday season when students could be absent from the classroom fell at the same time as the dry season in western Nicaragua. To skip for about seven weeks the rigors of a Vermont winter was another piece of good fortune. To be sure, there is no skiing in Nicaragua; not even on the highest mountains is there ever any snow.

To convey an idea of the climate of Nicaragua, figures on a thermometer mean far less than to mention that during many of the $\mathrm{nights}$ we needed no covering on our beds; in the coldest January nights a raincoat was an adequate cover. In Managua, we experienced one or two showers; otherwise, the sun was shining every day, all day long, from 6 a.m to 6 p.m. Although this was good for drying specimens, it was not always so good for humans. While our friends and families in Vermont were shivering with sub-zero blasts and roads we re choked with snow, sweat was dripping from our brows and noses and chins, with little or no exertion on our parts.

An important item in our equipment was field presses, each consisting merely of a pair of light-weight, almost frail slats, a supply of newspapers, and one light-duty strap. With few exceptions, as in the case of orchids and bromeliads, we pressed all our specimens within a few minutes of taking them. Thus, when leaves wilted, they wilted in position without curling. Folds were adjusted in the laboratory before putting them onto the dryer. Moreover, when we returned to our base, tired and hungry, there was less work to care for the day's booty. We believe that this method improved the quality of our specimens.

Nicaragua is divided into 15 departments, rather than states. To obtain samples of the flora from every department rather than to concentrate on any one area was our goal. With the aid of our automobile, we were able to accomplish this on our first trip except that we did not reach the department of Chinandega in the extreme northwest or Comarca del Cabo in the extreme northeast. It ought to be admitted however that we did not spend more than three of four days in the department of Zelaya, on the east (Atlantic) coast, which is larger in area than all the other departments combined. In this department our automobile could help us but little as only a small part of it can be reached from the west by roads. 
Geographically it is convenient to divide the land into two parts . The first, the western part, is a comparatively narrow strip of land along the Pacific Ocean, bounded on the east by mountain ranges which are a part of the enormous range extending from North America thru Central America far southward into South America. In this western strip lies Lake Nicaragua, one of the largest lakes in the world, famous for being the home of fresh water sharks. Also in this strip lies Lake Managua, a very large lake, even though much smaller than Lake Nicaragua. This western strip is extremely dry during the northern winter and therefore was so, at the time of our Expedition, in December and January. A few volcanoes are active and many of the mountains are extinct volcanoes.

If one proceeds eastwardfrom this dry western strip of land, he crosses mountain ranges and then enters the second part, a very different and much larger part of the country, subject to heavy rainfall and characterized by rain-forests. Much of this eastern area is included in the department of Zelaya. Its vegetation is extraordinarily different from that of the western strip. Ferns, for instance, are in great abundance and variety. The same may be said of the Melasto$\underline{\text { mataceae }}$, which are relatively scarce in the west but in the e a s t flourish in great abundance and bewildering variety.

Rather than enlarge further in a general account like this, a list of localities where we collected will be appended to this article, w it h more specific comments on the vegetation in each as we came to $i \mathrm{t}$.

The combined efforts of our eight men added up to about 8500 specimens of vascular plants, some of which came from 13 of the 15 departments. Only a brief visit of 3 or 4 days in Bluefields, Rama a n d El Recreo can be counted as an invasion of rain-forests. The e a s t e rn part of the country is less accessible than the western. Our experience in this first trip prepared us to reach more rain-forests another time, a year later, on our second trip. Tantalized by our tiny glimpse of rain-forests we were lured irresistably to return.

RECORD OF COLLECTIONS IN NICARAGUA

OF THE PRINGLE BOTANICAL EXPEDITION 1968-1969

The following records are arranged chronologically. The numbers are in one series. Each number is used only once, whoever is the collector.

Dec. 3. Grounds of the Escuela Nacional de Agricultura y Ganaderia (National School of Agriculture and Animal Husbandry), Managua, 
Dept. Managua, on Route 1, the Pan American Highway, $12 \mathrm{~km}$. north (actually east of this point) of the city of Managua, capital of the country. Seymour 1, a cultivated Canna. This collection serves as a $\mathrm{r}$ ecord that some of our party had arrived.

Dec. 4. Tipitapa, Dept. Managua, $22 \mathrm{~km}$ north (actually east a t this point) of the city of Managua. For our first collecting trip, w e selected a locality only $10 \mathrm{~km}$ from our headquarters, the Escuela. Tipitapa is characterized by mile after mile of cotton fields. The soil is black and fertile. The land is very level. While many rivers i n other parts of the country are dried up, streams in this area continue to flow. Altho at this season, the soil is very dry on the surface, un derneath the surface, a good water supply continues. Swamps and rivers are frequent. Dudey did not come on this trip and Seymour d i d not collect. Atwood and Moore had not yet arrived in Nicaragua. The others collected in a pasture, along a swamp and a muddy stagna $\mathrm{nt}$ creek. Hamblett 2-12; Narvaez 13-20; Nichols 21-36; Zelaya 37-52.

Dec. 5. Masaya, Dept. Masaya, shore of Lake Masaya. On the shore of a lake, we expected a fringe at least of well watered ground. On one side of the lake, such a fringe, if any, was exceedingly narrow. One foot from the water's edge, the soil was parched. On this side, some patches of ground were devoid of vegetation. Much of the s o i 1 was composed of volcanic clinkers,--very porous lumps of ash. Any plant must send its roots far below and between lumps to find moisture. Trucks were busy hauling away load after load of clinkers, presumably for road beds. Wigandia was one of the significant plants.

On the other side of the lake, huge blocks of lava, broken off from the cliffs above, cluttered the shore. Here grew a forest of tall trees. Dudey 53-71; Hamblett 72-90; Narvaez 91-98; Nichols 99-146; Seymour 147; Zelaya 148-161.

Dec. 6. Escuela, as described above. Located on the same kind of land as Tipitapa, they both are part of the vast plain, monotonously level, lying between the far western Cordillera del Pacifico, close to the Pacific Ocean, and the range of mountains which separates the dry western section from the region of rain-forests eastward. It is an ideal situation for the National School of Agriculture and Animal Husbandry, Nichols, only, 334-336.

Dec. 7. First stop. Not near a village, Dept. Managua, $25 \mathrm{~km}$ northwest of Managua on Route 12, in the Cordillera del Pacifico, which slopes abruptly westward to the Pacific Ocean. More moisture was in the soil here than in lower levels nearby. We collected on a s t e e p roadside bank and shady clay cliff. Hamblett and Nichols 162-194.

Dec. 7. Second stop. Telica, Dept. Leon, about $15 \mathrm{~km}$ north of the city of Leon, on Route 26. This spot was in full view of a volcano, Cerro Negro, belching forth black smoke which proved to consist of fine ash. As we came thru the city of Leon, it being directly to windward of $\mathrm{t} \mathrm{h}$ e volcano, people were sweeping and shoveling ash from the sidewalks. 
We collected in an open field. Dudey, Hamblett \& Nichols 195-210.

Dec. 7. Third stop. Telica, at a farm, near the second stop. Dudey, Hamblett \& Nichols 211-229. Here a crowd of cowboys gathered about us to see what kind of queer things we were doing. Altho there was no sign of anything unfriendly, we thot it better to move on.

Dec. 8. Masachapa, Dept. Managua, on the Pacific Coast, Route 8. Below the high water mark, the beach was of fine gray sand, usually packed hard, interspersed with barely exposed ledges of volcanic rock. It is a popular bathing beach. Our scanty collections, however, were made along the roadside. Nichols 230-239; Seymour 240242 .

Dec. 8. On our return, at the Escuela, Nichols 243-244.

Dec. 9. Atwood and Moore arrived at 9:30 a.m. by plane from Vermont. Since our presses were full, we collected only a little in the vicinity of the Escuela. Atwood 253-256; Narvaez 257-260, 460; Nichols 245-252, 881; Seymour 261-263; Zelaya 264-272.

Dec. 10. First stop, Santo Tomas, Dept. Chontales, Route 7. This was rich country approaching a rain-forest. While we stopped to refuel and get bottled soda, Nichols collected 273-286; and Seymour 289-291.

Dec. 10. Second stop. Rama, Dept. Zelaya, Route 7. While waiting for the boat to take half of our party down the Escondido River to Bluefields, we collected on the riverbank and at a spot $3 \mathrm{~km}$ north of the city. Rama is in rain-forest area. Atwood 289-291; Hamblett 292-297; Nichols 298-307; Seymour 308-317; Zelaya 318-321.

Dec. 10. Third stop. El Recreo, Dept. Zelaya, Route 7, about $32 \mathrm{~km}$ west of Rama. While half of our party were on the boat going to Bluefields, the rest of us stopped here to collect in rain-forest, among rolling hills. Dudey 322-325; Hamblett 326-329, 448- 459; Narvaez $330-333,461-463$.

Dec. 11. Bluefields, Dept. Zelaya. They collected along "open jungle trail." This was genuine rain-forest with rain descending much of the time while the men collected. The soil was clay. Atwood \& Moore 337-381, 882-892; Nichols 382-418; Zelaya 419-447.

Dec. 11. Rama. Atwood 897.

Dec. 12. Rama. They collected on a volcanic cone. Atwood \& Moore 464-490; Nichols 491-498; Zelaya 499-500. Nichols 898-899 at 
roadside.

Dec. 12. Casa Colorado, Dept. Carazo. While half of our party were in Rama, the others collected on a rather bleak mountain top in the Cordillera del Pacifico, among scrubby growth. Dudey 501 - 523; Hamblett 524-536; Narvaez 537-542; Seymour 543-578.

Dec. 13. Rama. Half of our party still in Rama collected in a rain-forest. Atwood 579-581; Atwood \& Moore 582-583; Nichols 584593, 900-904; Zelaya 594-601.

Dec. 13. Juigalpa, a few $\mathrm{km}$ south of the city, Route 7, Dept. Chontales. On the way back to Managua, Atwood \& Moore seized the opportunity of a brief stop to collect 602-603.

Dec. 14. First stop. El Bluff near Bluefields, Dept. Zelaya. While half of our party returned to Managua, now the other half had come to Bluefields. Setting out in the pouring rain (which soon ceased), we rented a motor boat which took us across the harbor to this narrow strip of land with water on both sides, salt water on the east, fresh water on the west. The soil was very sandy and the growth scrubby. A stiff wind made pressing our specimens very difficult. Dudey 604-610; Hamblett 611-626; Hamblett \& Seymour 627-630; Narvaez 631-634; Seymour 635-653.

Dec. 14. Second stop. Panta Masaya, near Bluefields. By the same boat, we who were at El Bluff reached a ridge extending intoBluefields Harbor, characterized by palms and cleared land; soil very moist. Dudey 654-671; Hamblett 672-681; Seymour 682-698.

Dec. 15. Bluefields. Only Seymour collected $699-714$, in a vacant lot, a weedy spot, in the city.

Dec. 16. Bluefields. As this half of our party left to return to Managua, Seymour hastily grabbed a Cyperus, 715, in a vacant lot.

Dec. 16. Rama. Second stop. While waiting for the bus to take us to Managua, Seymour again grabbed a few plants in a vacant lot,716-726.

Dec. 16. Third stop. Escuela. Atwood \& Moore 727-733; Zelaya 734-738.

Dec. 17-18. Escuela. All eight of us put specimens into press and went over those already in press.

Dec. 18. Escuela. Seymour 739 . 
Dec. 19. First stop. Escuela. Seymour 740-752.

Dec. 19. Second stop. Masachapa, Dept. Managua, on the Pacific Coast. The habitat was loose dry sand of the beach and scrubby growth above the beach. Only Nichols collected 753-754, 905-913.

Dec. 19. Third stop. $10 \mathrm{~km}$ west of La Concepcion, Route 8, still in Dept. Managua, in the Cordillera del Pacifico. Nichols 914918.

Dec. 20. First stop. Ocotal, Dept. Nueva Segovia, the only trip to this department. All eight of us collected $3 \mathrm{~km}$ west of the city, mostly in the bed of a dried-up brook in a deep gorge, but also on hillsides. This was very hilly country. Atwood 755-773; Dudey 774-788; Hamiblett 789-796, 798-803; Moore 804-815; Narvaez 1942-1945; Ni chols 816-839, 876-879; Seymour 840-872, 2239-2240; Zelaya 873-875.

Dec. 20. Second stop. Yalaguina, Dept. Madriz. On the way back to Managua, we stopped to collect at K203, $2 \mathrm{~km}$ south of Yala guina, along a river with stony bed on Route 1, the Pan American Highway. This was our only collecting in Dept. Madriz. Atwood 919-925; Dudey 925 (repeated by mistake)-927; Hamblett 797, 928-933; Moore 934-944; Nichols 945-955; Seymour 956-967; Zelaya 968-970.

Dec. 21-22. No collecting, as ventilators were all in use. We went over our specimens already in press.

Dec. 23. Matagalpa, Dept. Matagalpa. Zelaya alone, 971-979.

Dec. 23. Mechapa, Dept. Esteli, Route 1, Pan American Highway, at K129. Narvaez, Seymour and Zelaya did not go on this trip, the only one in the Dept. Esteli. Atwood 980-991; Dudey 1020-1029; Hamblett 992-993; Moore 994-999; Nichols 1000-1007.

Dec. 23. Second stop. Casas Viejas, Dept. Matagalpa, Route 1, at K73. Collected in a bog. Atwood 1008-1019; Dudey 1030-1038; Hamblett 1039-1043; Moore 1044-1055; Nichols 1056-1072.

Dec. 23. Escuela. Seymour 1073-1076.

Dec. 24. Granada, Dept. Granada, along shore of Lake Nicaragua. The soil was extremely dry except at water's edge and in a tiny cove. Atwood 1077-1097; Dudey 1098-1103; Hamblett 1104-1114; Moore 11151123; Nichols 1124-1142; Seymour 1143-1160. 
Dec. 24. Escuela. Seymour 1161-1162.

Dec. 25. Our third trip to Masachapa, Dept. Managua. To celebrate Christmas, we did the most outrageous thing we could think of; Atwood, Dudey, Hamblett, Moore and Seymour went swimming in the Pacific Ocean! Only' Seymour collected 1163-1172.

Dec. 26. No collecting. Errands filled the day.

Dec. 27. First stop. K136, southwest of La Virgen, Dept. Rivas, Route 16 , where road crossed a brook. The soil was very dry in spite of the brook. Much collecting was in the shade. A twood 1173-1187; Dudey 1220-1225; Hamblett 1188-1205; Narvaez 1206; Nichols 1207-1219, 1406-1407; Seymour 1226-1241; Zelaya 1242-1249.

Dec. 27. Second stop. San Juan del Sur, Dept. Rivas, Route 16. Sandy shore of Pacific Ocean near mouth of an estuary. Poor collecting. Atwood 1250; Dudey 1251-1252; Narvaez 1253-1259; Nichols 12601267, 1405; Seymour 1268-1269.

Dec. 27. Third stop. Santa Teresa, Dept. Carazo, Route 2. High steep clay bank and roadside-rill in mountains of the Cordillera del Pacifico. Atwood 1270-1284; Dudey 1285-1291; Hamblett 1292 1293, 1404; Moore 1296-1306; Nichols 1307-1322; Seymour 1323-1340.

Dec. 28. First stop. Escuela. Douglas Rodriguez Lacayo, not a member of our party, collected for us an epiphytic Bromeliad 1341; Atwood 1342-1346; Seymour 1347.

Dec. 28. Second stop. Managua, Route 2, K7, south of city, on the Pan American Highway, near a volcanic crater. Some soil consisted of volcanic clinkers like those at Lake Masaya. When we attempted to reach the shore of the lake which filled the bottom of the crater, the bank was so steep and the clinkers so loose that we could not get a footing; the attempt had to be abandoned. We collected on stratified sandstone and on a hill, both high above the rim of the crater. Atwood 1348; Nichols 1349-1353; Seymour 1354-1358.

Dec. 29. First stop. Masachapa again, Route 8. We collected in scrubby growth just above high water mark and along a dried-up creek in very sandy soil. Hamblett 1359; Nichols 1360-1388; Seymour 1389-1400.

Dec. 29. Second stop. $4 \mathrm{~km}$ southwest of $\mathrm{El} \mathrm{Crucero,} \mathrm{Route} 8$, in the Cordillera del Pacifico, Dept. Managua. Moore 1401; Sey mour 1402-1403. 
Dec. 30. First stop. Boaco, Dept. Boaco, Route 9, in mountains just west of the city. We collected in rich woods and open spots. A t wood 1408-1423; Dudey 1424-1447; Hamblett 1448-1455; Mo o r e 14561461; Nichols 1462-1483; Seymour 1484-1497.

Dec. 30. Second stop. City of Boaco. About pavements, Nichols 1498; Seymour 1499-1500.

Dec. 30. Third stop. Escuela. Nichols 1501-1504.

Dec. 31. First stop. Puerto Momotombo, Dept. Leon. Collected in a wide meadow on the shore of Lake Managua. A tw ood 1505-1521; Dudey 1522-1535; Hamblett 1536-1539; Moore 1540-1548; Seymour 1555 -1563 .

Dec. 31. Second stop. Leon Viejo, Dept. Leon. Sightseeing in the partially excavated ruins of the ancient city buried many years ago in volcanic ash. The ground was parched; the soil was black, deeply covered with powdery dust. The heat was almost unbearable. Atwood 1549-1552; Seymour 1553-1554.

Jan. 1. Holiday. No collecting.

Jan. 2. Holiday. Escuela. Seymour 1564, an alga.

Jan. 3. K12 1/2, Route 1, 1/2 km east of the Escuela. Three of us collected by the roadside and in low land in rich black soil. Atwood 1565-1575; Nichols 1576-1581; Seymour 1582-1592.

Jan. 4. First stop. Juigalpa, Dept. Chontales, Route 7, $5 \mathrm{~km}$ southeast of the city. We collected by the roadside and in swam py woods where we should like to have stayed longer but felt we must press on to our main objective. Nichols 1593-1600; Dudey 1601-1607; Hamblett 1608-1619; Moore 1620-1634; Nichols 1635-1645; Seymour 1646-1648.

Jan. 4. Second stop. $2 \mathrm{~km}$ southeast of Acoyapa, Dept. Chontales. On this trip, we were attempting to reach San Carlos. Some maps showed a road all the way from Acoyapa to San Carlos. Beyond A c oy a pa the road became less improved. $2 \mathrm{~km}$ southeast of Acoyapa, the road petered out in a swamp. Doubtless an army could get thru to San Carlos, but not an ordinary automobile. We collected in a damp low pasture and hillside, in rolling country. Atwood 1649-1660; Dudey 1661-1683; Hamblett 1684-1700; Moore 1701-1712; Narvaez 1713-1718; Nichols 1719-1752; Seymour 1753-1786. 
Jan. 4. Third stop. $1 \mathrm{~km}$ southeast of Acoyapa. On the return trip, while other members of the party attempted to photograph a flock of vultures feeding on a dead horse, Seymour collected 1787-1798 in an open field.

Jan. 5. Sunday. No collecting. Care of specimens collected yesterday.

Jan. 6. Matagalpa, Dept. Matagalpa, Route 3. Zelaya alone, 1799-1806. This was his home town.

Jan. 7. First stop. Granada, Dept. Granada, Route 4 . By 6 a. m., we were on the road. At the boat wharf, we arrived two hours too late to catch the boat to San Carlos, thanks to misinformation. Nichols 1807, Lemna minor L.

Jan. 7. Second stop. Having missed the boat for San Carlos, we set out for the Dept. Rivas and collected in that department only for the rest of the day. Without stopping again we drove to the boundary of Costa Rica, on Route 2, the Pan American Highway. Turning back, our second stop where we collected anything was $1 \mathrm{~km}$ north of the boundary, near the village of Penas Blancas. Most of the soil was very dry, but it was not so dry in ditches. Atwood 1808-1815; Hamblett 1816-1822; Moore 1823-1833; Narvaez 1834-1837; Nichols 1838-1849; Seymour 18501867 .

Jan. 7. Third stop (called second stop in my notes), Route 2, K 142, near village of Sapoa. Here the stream by which we stopped wa s not dried up; collecting was better. Atwood 1868-1873; Hamblett 18741878; Narvaez 1879; Seymour 1880-1887.

Jan. 7. Fourth stop. K 137, Route 2, $5 \mathrm{~km}$ northwest of Sapoa by a river. This river was full, altho a few feet from it, the ground seemed parched. Nichols, in his zeal on finding a river not dried up, reached for some Salvinia and slid off the steep bank into the river. Nichols could not swim! Hamblett being nearest heard his call for help and pulled him out. Atwood 1888-1894; Narvaez 1895; N i c hols 1896-1897a; Seymour 1898-1905.

Jan. 7. Fifth stop. K 97, Route 2, near village of Belen. Here the ground was so dry that we walked thru the woods in the perfectly 
dry bed of a river. Atwood 1906-1908; Moore 1909-1917; Seymour 19181921.

Jan. 7. Sixth stop. Route 2, Puente Las Cabezas, northwest of Belen. The river did not produce as interesting a vegetation as we hoped when we sighted the bridge and decided to stop. Atwood 1922-1925; Hamblett 1926; Moore 1927-1929; Seymour 1930-1940.

Jan. 7. Seventh stop. Escuela. The indefatigable Nichols collected another number, 1941, some kind of Mistletoe.

Jan. 8. The day was occupied with caring for yesterday's collections.

Jan. 9. Having been defeated in our attempt to reach San Carlos via Acoyapa and our automobile, we concluded that there is no road to that city. Intrepid Atwood and Hamblett determined to reach San Carlos at all costs and to sample its flora. Dudey, Moore and Nichols accompanied them to the wharf in Granada. Then the latter three proceeded a short distance to Mombacho, one of the highest volvanic mountains in the country. Here they found the lush tropical vegetation which they had expected in Nicaragua but had seen only briefly in and around B $1 \mathrm{u}$ e fields, Rama and El Recreo. This mountain is $12 \mathrm{~km}$ southwest of Granada and rises to a height of $1222 \mathrm{~m}$. The collections were made part way up the mountain. Dudey \& Moore 1948-1993; Nichols 1994- 2014 ; 2207-2212.

Jan. 9-10. The boat trip to San Carlos proved exhausting. A distance of only $155 \mathrm{~km}$, which could easily have been made in half a day by automobile on a good road, took $231 / 2$ hours. Probably a head wind and rough water contributed largely to the delay. The most luxurious sleeping quarters afforded were sacks of meal piled on deck. Worn out before arrival, Atwood and Hamblett hastily grabbed specimens as fast as they could for two hours and then hurried to the wharf to catch the next boat back to Granada. Under almost any other circumstances, the flora would have been intriguing. Vegetation was lush, as could be expected in an area of rain-forests. It beckons for another trip with more time to obtain a fair sample of its flora. Atwood 2015-2049a; Hamblett 2050-2072.

Jan. 10. Nichols left to return to Vermont. 
Jan. 11. Managua, city street. Seymour 2015, Eragrostis cilianensis (All.) E. Mosher. This weed, wide-spread in some countries was not seen elsewhere in Nicaragua.

Jan. 11. Second stop. Santa Maria, Route 3, a few $\mathrm{km}$ north of Matagalpa, Dept. Matagalpa. This was one of the most beautiful spots seen in all our roaming over the country. A fashionable cool resort in the mountains, where one can escape the intense heat which prevails over much of Nicaragua. The premises are beautifully landscaped and planted with strikingly beautiful and unusual shrubs and trees. Atwood 2074, 2081-2085; Seymour 2075-2080.

Jan. 11. Third stop. Continuing northward on Route 3, passing thru the city of Jinotega, we stopped $10 \mathrm{~km}$ north of that city, ne a r what is represented on the map as a lake. So far as we could see, there were only patches of open water, broken by islands of mud a n d vegetation. Our collecting spot was near La Bastilla and Pueblo $\mathrm{Nu}-$ evo. The swamp bordering the lake seemed inaccessible but we were kept busy getting plants not difficult to reach, on a wooded slope. Atwood 2086; Dudey 2100-2102; Moore 2103-2116; Seymour 2117 - 2142, 2213; Zelaya 2143-2149.

Jan. 12. Returning to Santa Maria for recreation the next day, Sunday, we had more time to satisfy our curiosity roused by glimpses the day before. Atwood 2149a-2151, 2202-2206, 2214-2216; Seymour 2152-2201, 2217-2219.

From this day onward, packing and shipping our 8500 specimens demanded nearly all our time.

Jan. 16. With the shipment safely arranged at last by air-freight and some specimens stowed in the automobile to be brought to Vermont thus, Atwood and Seymour made a short foray only $2 \mathrm{~km}$ eastward beyond the Escuela along the Pan American Highway. One need not go far from a highway to find species new to him. Atwood 2220-2225a; Seymour 22262238 .

Jan. 18. Hamblett took an early plane from Managua to Burlington. Atwood and Seymour followed by plane later the same day.

Of the Vermonters, only Dudey and Moore remained a few days longer to bring home our Camper and the specimens in it. As fa $r$ as Mexico City, they proceeded together. Then Moore also took to the air. Dudey drove the rest of the distance, sightseeing and visiting along the way. 
While the collections of Harvey Zelaya M. during the summer of 1969 are not part of the Pringle Expedition, they are being distributed together by Frank C. Seymour and are numbered in the same series. Therefore their record belongs here.

July 9. Escuela, 2241-2248. July 10. 2249-2250.

July 11. Matagalpa, Dept. Matagalpa, 2273-2283.

July 14. Escuela, 2251-2253. July 15. 2254-2258.

July $17.2259-2264$.

July 19. Matagalpa, 2284-2297. July 22. 2298-2305.

July 23 . Matagalpa, 2306-2325. July 24 . 2326-2328.

July 29. Escuela, 2265-2267. July 30. 2268-2272.

Aug. 8. Nindiri, Dept. Masaya, 2329.

Santiago, Dept. Masaya, 2330-2331.

How can we estimate the success of such an expedition? By the number of specimens collected? All together, we netted 8500, not including the 850 taken by Zelaya in the summer afterward. This is an average of 1062 per man in not quite 7 weeks. Shall we estimate success in terms of our permanent contribution to man's knowledge of a little-known part of the world? Both of these must count but also we can take into account the explorers' own evaluation. It is significant that every one of the eight men wanted to go again!

(It is intended to publish similar accounts of subsequent trips in later numbers of Phytologia. Two other trips in 1970 and 1971, respectively, have already been made. A fourth trip is planned for the summer of 1972.) 


\section{N I C A R A G U A \\ Pringle (First) \\ Botanical Expedition 1968-1969}

Localities of collections marked by black circles.

Departments by number

1. Boaco

2. Carazo

3. Chinandega

4. Chontales

5. Comarco del Cabo

6. Esteli 12. Masaya

7. Granada

8. Jinotega

13. Matagalpa

9. Leon

14. Nueva Segovia

10. Madriz

15. Rio San Juan

11. Managua

16. Rivas

17. Zelaya 


\section{$2 \mathrm{BHL}$ Biodiversity Heritage Library}

Seymour, F C. 1972. "A botanical expedition to Nicaragua." Phytologia 22, 441-454. https://doi.org/10.5962/bhl.part.26933.

View This Item Online: https://www.biodiversitylibrary.org/item/48967

DOI: https://doi.org/10.5962/bhl.part.26933

Permalink: https://www.biodiversitylibrary.org/partpdf/26933

\section{Holding Institution}

New York Botanical Garden, LuEsther T. Mertz Library

\section{Sponsored by}

The LuEsther T Mertz Library, the New York Botanical Garden

\section{Copyright \& Reuse}

Copyright Status: In copyright. Digitized with the permission of the rights holder.

Rights Holder: Phytologia

License: http://creativecommons.org/licenses/by-nc-sa/3.0/

Rights: https://biodiversitylibrary.org/permissions

This document was created from content at the Biodiversity Heritage Library, the world's largest open access digital library for biodiversity literature and archives. Visit BHL at https://www.biodiversitylibrary.org. 